\title{
Fungsi Kompetensi Kepribadian Pendidik Anak Usia Dini dalam Proses Penyesuaian Diri Siswa Baru
}

\author{
Laily Hidayati \\ STAI Al Hikmah Tuban \\ Email: lailykusturayu@gmail.com
}

\begin{abstract}
A competent teacher is a teacher who is committed to his job and his job as an educator, an effective class manager, a positive role model identifiable and imitated by his students, warm and enthusiastic about student ideas, constantly improving himself in teaching techniques, improving his skills in Social relations, and can adapt their skills in a specific context. Children or students learn optimally if the teacher can run his role as a model or model, who loves his profession as a teacher. This paper is a conceptual paper which is the result of a discussion between field observations of the researcher, early childhood educator experience, as well as previous theoretical and research studies focusing on the early childhood adjustment process in a new class or school. This paper is expected to present descriptive data about the educator's personality function that influences the process of adjustment of new students in early childhood education, so it is expected to contribute thoughts and practical benefits for early childhood education institutions in assisting the adaptation process of students in the new school year, Through the enhancement of the educational competence of its educators.
\end{abstract}

Keywords: Personality Competence, Adjustment, Early Childhood. 


\section{PENDAHULUAN}

Anak usia dini adalah anak yang baru dilahirkan sampai usia 6 tahun Sujiono (2009). Usia ini merupakan usia yang sangat menentukan dalam pembentukan karakter dan kepribadian anak. Usia dini merupakan usia dimana anak mengalami pertumbuhan dan perkembangan yang pesat sehingga diperlukan stimulasi yang tepat. Pasal 28 UU Sisdiknas No.20/2003 ayat 1 menyatakan bahwa "rentangan anak usia dini adalah dari usia 0 sampai 6 tahun". Sementara menurut kajian rumpun keilmuan PAUD dan penyelenggaraannya di beberapa negara, PAUD dilaksanakan sejak usia 0-8 tahun, sebagaimana menurut National Assosiation Education for Young Children (NAEYC), yang menyebutkan bahwa Anak Usia Dini adalah sekelompok individu yang berada pada rentang usia antara 0 - 8 tahun.

Terdapat berbagai kajian tentang penyelenggaraan pendidikan anak usia dini, khususnya anak TK, di antaranya yang dilakukan oleh Bredecam dan Copple, Brener, serta Kellough (Masitoh, 2005) yang menemukan beberapa penemuan karakteristik pendidikan anak usia dini sebagai berikut.

1. Anak bersifat unik.

2. Anak mengekspresikan perilakunya secara relatif spontan.

3. Anak bersifat aktif dan enerjik.

4. Anak itu egosentris.

5. Anak memiliki rasa ingin tahu yang kuat dan antusias terhadap banyak hal.

6. Anak bersifat eksploratif dan berjiwa petualang.

7. Anak umumnya kaya dengan fantasi.

8. Anak masih mudah frustrasi.

9. Anak masih kurang pertimbangan dalam bertindak.

10. Anak memiliki daya perhatian yang pendek.

11. Masa anak merupakan masa belajar yang paling potensial.

12. Anak semakin menunjukkan minat terhadap teman.

Masa kanak-kanak merupakan masa yang penting dalam perkembangan hidup usia karena masa kanak-kanak merupakan masa paling awal dalam rentang kehidupan akan menentukan perkembangan pada tahap-tahap selanjutnya. Pada tahap perkembangan anak usia prasekolah ini, anak mulai menguasai berbagai ketrampilan fisik, dan anak pun mulai memiliki rasa percaya diri untuk mengeksplorasian diriannya (Hurlock, 1997). Tugas perkembangan awal masa kanak-kanak yang penting adalah memperoleh pengalaman pendahuluan 
yang diperlukan untuk menjadi anggota "kelompok" akhir masa kanak-kanak (Hurlock,1991). Ketika anak memasuki lingkungan sekolah yang baru, ia akan mulai menghadapi tantangan baru, yaitu dalam aspek sosialisasinya. la membutuhkan keterampilan untuk menjalin pertemanan baru dengan teman maupun guru dan lingkungan sekolah secara umum, dan pada saat yang sama ia dituntut untuk mulai mandiri dan mengurangi kelekatannya dengan figur orangtua yang sebelumnya bersifat utama dalam perkembangan sosial emosionalnya. Oleh karena itu penyesuaian diri merupakan salah satu hal yang penting dalam menentukan keberhasilan seseorang dalam berkelompok memenuhi tuntutan lingkungan sekitarnya.

Anak prasekolah dituntut untuk mampu menyesuaikan diri dengan berbagai orang dari berbagai tatanan, yaitu keluarga, sekolah, dan teman sebaya (Patmodewo, 2000), namun pada kenyataannya sangat berlainan. Terlihat banyak anak yang belum bisa ditinggal oleh orangtua meskipun pelajaran sudah berjalan dan sebagian teman-temannya telah mampu menyesuaikan diri dan menjalin pertemanan baru. Biasanya, sekolah hanya memberikan masa orientasi dan masa orangtua untuk dapat berpisah dengan anak selama dua minggu saja. Atau, di beberapa sekolah, orangtua, umumnya ibu, memerlukan waktu sampai satu bulan lebih sampai dapat benar-benar meninggalkan anaknya di kelas bersama temanteman dan gurunya. Sebagaimana pengamatan yang dilakukan di RA. Hidayatus Shibyan Wanglukulon Senori Tuban.

Berbagai indikator perilaku yang menunjukkan belum mampunya siswa baru anak menyesuaikan diri dengan lingkungan sekolah yang baru antara lain adalah: meminta ibu untuk selalu berada di dekatnya, menangis jika ibu menjauh atau tidak terlihat, menolak mengikuti kegiatan pembelajaran jika tidak ditemani ibu, menolak bermain bersama teman sama sekali, atau dapat bergabung dalam permainan kelompok hanya jika ditunggui oleh ibu. Saat pembelajaran, sebagian dari mereka ada yang lari dari kelas untuk mencari dan mendekati orangtua, khususnya untuk anak yang masih ditunggu orangtua di luar kelas, bahkan masih sering terjadi di antara mereka yang menangis sambil mengejar orangtuanya sampai keluar dari pintu gerbang sekolah saat jam masuk sekolah.

Masalah penyesuaian diri di sekolah menimbulkan efek yang menetap dan bertumpuk-tumpuk, masalah yang muncul pada awal karir sekolah anak sering menjadi masalah yang menetap 
karena faktor sosial-psikologis dan memperburuk keadaan saat kesulitan mulai muncul dan menghambat perkembangan selanjutnya (Suprobo, 2008). Penyesuaian diri dan kemandirian sangat berperan penting terhadap perkembangan emosi peserta didik, dimana untuk membentuk pribadi yang wibawa dan cakap dilingkungannya (Jaya, 2012).

Hurlock (2003) mengungkapkan bahwa penyesuaian diri merupakan kemampuan untuk menyesuaikan diri terhadap orang lain yang berarti sejauh mana individu bereaksi secara efektif terhadap hubungan, situasi dan kenyataan sosial. Menurut Ahmadi (1991), penyesuaian diri diartikan pula dengan mengubah lingkungan sesua lingkungan sendiri. Jadi setiap perubahan yang terjadi dalam kehidupan individu menyebabkan individu selalu berusaha menyesuaikan diri dengan lingkungan. Sejalan Davidoff (Fatimah, 2006), adjustment merupakan suatu proses untuk mencari titikntara kondisi diri dan tuntutan lingkungan. Schneiders (Hurlock, 1994) menyatakan bahwa penyesuaian diri adalah prosesapan mental dan tingkah laku seseorang dalam menghadapi tuntutan-tuntutan baikdalam diri sendiri maupun dari lingkungannya. Penyesuaian diri ditentukan olehana seseorang dapat bergaul dengan diri sendiri dan orang lain secara baikapan-tanggapan terhadap orang lain atau lingkungan sosial pada umumnya dapaang sebagai cermin apakah seseorang dapat melakukan penyesuaian dengan baikak. Sejalan dengan Fatimah (Sobur, 2003), penyesuaian diri diartikan sebagai suatu dinamika terus-menerus yang bertujuan untuk mengubah perilaku untuk mendapatkanan yang lebih serasi antara diri dan lingkungan.

Uraian di atas menunjukkan bahwa karakteristik khusus yang melekat pada anak usia dini, mengharuskan lingkungan, dalam hal ini orangtua dan guru, memberikan perlakuan yang tepat dan sesuai dengan tahapan usia anak, sehingga perlakuan yang tepat tersebut dapat membantu tercapainya tugas perkembangan yang sedang dan akan dilalui oleh anak. Peran penting pendidik atau guru dalam proses sosialisasi serta tumbuh kembang anak, dilaporkan oleh Good \& Brophy, 2007; Linney \& Seidman, 1989 dalam penelitiannya bahwa,

"a competence teacher is one who is committed to work, is an effective classroom manager, is a positive role model with whom student can identify, is enthusiastic and warm, continous effort for self improvement in teaching, possesses skill in human relationship, and can adapt his or her skill to a specific context". 
Guru yang kompeten adalah guru yang berkomitmen terhadap pekerjaan dan tugasnya sebagai pendidik, seorang manajer kelas yang efektif, teladan yang positif yang dapat diidentifikasi dan ditiru oleh siswanya, hangat dan antusias terhadap ide-ide siswa, selalu memperbaiki dirinya dalam teknik pengajaran, memperbaiki keterampilannya dalam hubungan sosial kemasyarakatan, dan dapat mengadaptasikan keterampilannya dalam konteks yang spesifik. Selain itu juga kajian yang dilakukan oleh Brophy, 1992 (Berns 2010), menguraikan bahwa "the most powerful socializing influence of the school lies in those who translate program goals into action, the teacher". Bahwa pengaruh sosial paling kuat berasal dari seseorang yang dapat menerjemahkan program-program sekolah ke dalam kegiatan-kegiatan nyata, yaitu guru. Serta apa yang disampaikan oleh Kohl, 1984 (Berns 2010) bahwa "children learn best from teachers who are role models, who love learning". Bahwa anak-anak atau siswa belajar secara optimal jika guru dapat menjalankan perannya sebagai model atau teladan, yang mencintai pembelajaran. Ketiga uraian peran penting pendidik dalam sosialisasi serta tumbuh kembang anak di atas, senada dengan apa yang ditemukan oleh Schickedanz, 1990 dalam penelitiannya (Berns 2010) bahwa "teacher's verbal styles have been found to have an impact on the development of language skill in pre-school children"

Dalam Undang-Undang Republik Indonesia (UU RI) nomor 14 tahun 2005 tentang Guru dan Dosen BAB I Ketentuan Umum Pasal 1 disebutkan bahwa yang dimaksud dengan "Kompetensi" adalah seperangkat pengetahuan, keterampilan dan perilaku yang harus dimiliki, dihayati, dan dikuasai oleh guru atau dosen dalam melaksanakan tugas kerpofesionalan. Sebagai seorang pendidik PAUD yang profesional, hendaknya perlu juga mengetahui standar kompetensi yang harus dimiliki tersebut, sehingga tugas utama pendidik dalam membimbing, memotivasi dan memfasilitasi kegiatan pengasuhan serta pendidikan peserta didik PAUD dapat berjalan dengan optimal. Lebih lanjut dijelaskan, dalam Peraturan Pemerintah Nomor 19 Tahun 2005 yang mengatur Standar Nasional Pendidikan Bab VI mengenai Standar Pendidik dan Tenaga kependidikan, Bagian Kesatu tentang Pendidik, Pasal 28 Ayat 3, menyebutkan bahwa kompetensi yang harus dimiliki guru sebagai agen pembelajaran pada jenjang pendidikan dasar dan menengah, serta pendidikan anak usia dini, termasuk di dalamnya guru pendidikan anak usia dini, meliputi: kompetensi pedagogik, 
kompetensi professional, kompetensi sosial, serta kompetensi kepribadian.

Tulisan ini adalah tulisan konsepsional yang merupakan hasil diskusi antara pengamatan lapangan peneliti, pengalaman pendidik anak usia dini, serta kajian teori dan hasil penelitian terdahulu yang berfokus pada proses penyesuaian diri anak usia dini di kelas atau sekolah baru. Tulisan ini diharapkan dapat menyajikan data deskriptif tentang fungsi kepribadian kepribadian pendidik yang mempengaruhi proses penyesuaian diri siswa baru pada jenjang pendidikan anak usia dini, sehingga diharapkan dapat memberikan sumbangan pemikiran serta manfaat praktis bagi lembaga pendidikan anak usia dini dalam membantu proses adaptasi siswanya pada tahun ajaran baru, melalui peningkatan kompetensi kepribadian pendidikpendidiknya.

\section{DISKUSI}

Hasil penelitian terdahulu yang dilakukan oleh Ani Susanti, menunjukkan bahwa faktor yang mempengaruhi penyesuaian diri pada anak Taman Kanak-kanak adalah faktor psikologis, lingkungan prenatal, pengalaman belajar, kondisi lingkungan, pola asuh orantua/keluarga. Faktor tersebut lebih didominasi oleh faktor eksternal. Dinamika Penyesuaian diri pada anak Taman Kanak-kanak diawali dari adanya kecemasan dari anak saat berpisah dengan orangtuannya, menangis, dan penarikan pada awal masuk sekolah. Adanya kerjasama guru dengan orangtua dalam memberikan motivasi dan pendampingan yang lebih intensif menjadikan anak mulai dapat menyesuaikan diri di sekolah. Kesimpulan dalam penelitian ini bahwa faktor eksternal lebih mempengaruhi penyesuaian diri pada anak Taman Kanak-kanak. Dinamika penyesuaian diri pada anak yang awalnya memiliki penyesuaian diri yang kurang, dengan adanya kerjasama guru dengan orangtua dalam memberikan motivasi dan pendampingan yang lebih itensif menjadikan anak mulai dapat menyesuaikan diri di sekolah. Tulisan ini memfokuskan kajian pada peran dan fungsi kompetensi kepribadian guru untuk membantu proses penyesuaian diri siswa baru pada pendidikan jenjang usia dini.

Dalam Undang-Undang Republik Indonesia (UU RI) nomor 14 tahun 2005 tentang Guru dan Dosen BAB I Ketentuan Umum Pasal 1 disebutkan bahwa yang dimaksud dengan kompetensi adalah: 
"Seperangkat pengetahuan, keterampilan dan perilaku yang harus dimiliki, dihayati, dan dikuasai oleh guru atau dosen dalam melaksanakan tugas kerpofesionalan. Sebagai seorang pendidik PAUD yang profesional, hendaknya perlu juga mengetahui standar kompetensi yang harus dimiliki tersebut, sehingga tugas utama pendidik dalam membimbing, memotivasi dan memfasilitasi kegiatan pengasuhan serta pendidikan peserta didik PAUD dapat berjalan dengan optimal.".

Lebih lanjut dijelaskan, dalam Peraturan Pemerintah Nomor 19 Tahun 2005 yang mengatur Standar Nasional Pendidikan Bab VI mengenai Standar Pendidik dan Tenaga kependidikan, Bagian Kesatu tentang Pendidik, Pasal 28 Ayat 3, menyebutkan bahwa kompetensi yang harus dimiliki guru sebagai agen pembelajaran pada jenjang pendidikan dasar dan menengah, serta pendidikan anak usia dini, adalah empat ranah kompetensi, yaitu: kompetensi pedagogik, kompetensi sosial, kompetensi professional, serta kompetensi kepribadian.

1. Kompetensi Pedagogik, yaitu kemampuan seseorang dalam mengelola pembelajaran peserta didik yang meliputi pemahaman terhadap peserta didik, perancangan dan pelaksanaan pembelajaran, evaluasi dan hasil belajar, dan pengembangan peserta didik untuk mengaktualisasikan berbagai potensi yang dimilikinya. Beberapa kemampuan yang ada dalam kompetensi pedagogik ini adalah:

a. Memahami karakteristik, kebutuhan dan perkembangan anak didik.

b. Menguasai dasar-dasar pendidikan anak usia dini.

c. Menguasai prinsip dan pendekatan bermain sambil belajar.

d. Menguasai dasar-dasar bimbingan.

2. Kompetensi Sosial, yaitu kemampuan seseorang sebagai bagian dari masyarakat untuk berkomunikasi dan bergaul secara efektif dengan peserta didik, sesama pendidik, tenaga kependidikan, orangtua atau wali peserta didik dan masyarakat sekitar. Beberapa kemampuan yang ada dalam kompetensi sosial ini adalah:

a. Memahami anak dalam konteks keluarga dan masyarakat.

b. Menguasai komunikasi dengan anak. 
c. Mampu bekerjasama dengan orangtua anak, pihak pemerintah, dan masyarakat untuk kepentingan pendidikan anak.

3. Kompetensi Profesional, yaitu kemampuan seseorang dalam penguasaan materi pembelajaran secara luas dan mendalam yang memungkinkannya membimbing peserta didik, memenuhi standar kompetensi yang ditetapkan. Beberapa kemampuan yang ada dalam kompetensi profesional ini adalah:

a. Menguasai menu pembelajaran yang berorientasi perkembangan (fisik, sosial, emosional, kognitif, bahasa, dan seni)

b. Menguasai pengembangan program yang sesuai dengan kebutuhan dan perkembangan anak.

c. Menguasai berbagai strategi pembelajran yang sesuai dengan perkembangan anak.

d. Menguasai pemanfaatan lingkungan sebagai sumber belajar.

e. Menguasai pengelolaan pembelajaran yang bervariasi, menyenangkan dan menantang, yang berorientasi pada perkembangan.

f. Menguasai penilaian yang sesuai dengan karakteristik perkembangan anak.

4. Kompetensi Kepribadian, yaitu kemampuan kepribadian yang mantap, stabil, dewasa, arif dan berwibawa, menjadi teladan bagi peserta didik dan berakhlak mulia. Beberapa kemampuan yang ada dalam kompetensi kepribadian ini adalah:

a. Memiliki kepekaan terhadap perasaan dan pikiran anak.

b. Menghargai perbedaan, keunikan individu, cepat tanggap menanggapi kesulitan anak.

c. Memiliki rasa peduli, empati dan responsif serta mampu memberi dorongan kepada anak.

d. Memiliki rasa kasih sayang, kesabaran, kehangatan, keluwesan, kejujuran, penuh perhatian, dan bersikap objektif. 
Indikator Kompetensi Kepribadian Pendidik Menurut Peraturan Pemerintah (PP) No. 19 Tahun 2005 yang mengatur Standar Nasional Pendidikan Bab VI mengenai Standar Pendidik dan Tenaga kependidikan, Bagian Kesatu tentang Pendidik, Pasal 28 Ayat 3, dapat kita analisis dalam konteks kebutuhan dasar dalam stimulasi atau pendidikan anak usia dini sebagai berikut::

1. Memiliki kepekaan terhadap perasaan dan pikiran anak. Kepekaan ini dibutuhkan oleh pendidik untuk memahami kondisi emosional serta tahapan perkembangan kognitif anak didiknya. Terlebih pada anak usia dini dimana tahap perkembangan emosional dan kognitifnya masih pada tahap egosentris, yaitu tahap dimana anak belum dapat menempatkan dirinya pada sudut pandang orang lain, sehingga seringkali dalam interaksi soialnya bersama teman-temannya menimbulkan gesekan-gesekan yang sangat mungkin mengganggu proses pembelajaran secara umum. Kepekaan juga dibutuhkan saat anak usia dini belum dapat mengungkapkan perasaan yang mengganggunya atau menghalanginya untuk belajar bersama teman-temannya. Hal tersebut disebabkan oleh keterampilan memahami dan mengungkapkan emosi pada anak, sehingga pendidik lah yang harus peka melihat tanda-tanda perubahan fisikdan perilaku anak. Misalnya menjadi murung, menjadi "tidak seperti biasanya", menolak masuk lingkaran, kurang bersemangat mewarna, dll. Pada siswa baru, kompetensi ini dibutuhkan untuk menghadapi siswa secara dengan terlebih dahulu memahami bahwa perpisahan dengan ibu untuk memasuki kelas baru adalah hal yang cukup berat bagi seorang anak. Guru dengan kepekaan ini akan dapat memahami perasaan siswa sehingga ia tidak terburu-buru dan lebih bersabar untuk menunggu dan memberikan kesempatan kepada siswa untuk belajar menyesuaikan diri di sekolah baru.

2. Menghargai perbedaan, keunikan individu, cepat tanggap menanggapi kesulitan anak. Kemampuan ini diawali dengan keharusan memahami bahwa setiap anak adalah unik, atau yang dalam psikologi disebut dengan individual differences. Keunikan individual ini dibutuhkan oleh pendidik agar dapat menghargai dan mengapresiasi setiap ide dan gagasan maupun permasalahan anak didiknya sehingga setiap anak dapat tumbuh penuh percaya diri menjadi dirinya sendiri, dengan jatidirinya sendiri. Kemampuan ini juga diperlukan agar pendidik tidak 
menetapkan standar proses dan hasil belajar secara kaku tanpa toleransi terhadap perbedaan-perbedaan gaya belajar dan pencapaian individual. Contohnya pada anakanak yang memiliki gaya belajar kinestetik dimana dalam belajar ia banyak bergerak dan cenderung membuat kelas gaduh. Anak-anak seperti ini membutuhkan seorang pendidik yang dapat memahami bahwa dirinya memang memproses informasi (pelajaran) dengan sambil bergerak, yang kemudian pendidik tidak secara serta merta melabelnya sebagai anak yang "tidak bisa diam" atau bahkan sebutan "nakal". Cepat tanggap adalah sikap yang dibutuhkan oleh pendidik untuk sewaktu-waktu merespon kejadian-kejadian mulai yang sederhana hingga yang kompleks yang terjadi pada satu anak saja, atau yang melibatkan keseluruhan atau lebih banyak anak di dalam kelas atau di sekolah. Dalam masa tahun ajaran baru, akan tampak sekali pemandangan di sekolah bahwa masingmasing anak membawa tingkat kesiapan sosial emosional yang berbeda. Guru yang kompetensi dan dapat menghargai perbedaan serta keunikan anak, tak akan membandingkan satu dengan yang lain, akan tetapi ia akan secara bijak memandang anak sebagai dirinya sendiri, dengan latar belakang keluarga yang berbeda, sosial ekonomi, kesehatan, serta usia dan kematangan perkembangan yang berbeda pula.

3. Memiliki rasa peduli, empati dan responsif serta mampu memberi dorongan kepada anak. Peduli dan responsif dibutuhkan oleh pendidik anak usia dini dalam situasisituasi yang membutuhkan penanganan cepat pada anakanak usia dini yang masih belum dapat sepenuhnya mandiri dan melayani dirinya sendiri. Anak terjatuh, anak berebut mainan, anak menangis dan rewel atau yang sering disebut dengan temper tantrum, dll. Empati dibutuhkan untuk mendengarkan semua ungkapan emosi dan pikiran anak, baik yang positif maupun yang negatif. Positif misalnya adalah ungkapan tentang kebanggaan anak dapat mewarna tuntas, ungkapan kebanggaan memiliki buku baru, cerita tentang mainannya di rumah, dll. Yang negatif misalnya adalah ungkapan ketika si anak merasa jengkel dengan temannya karena membuatnya terjatuh saat di lapangan, merusakkan kertas origaminya, kemarahan, kecemburuan, mencari perhatian, dll. Pada masa penyesuaian diri siswa baru, kemampuan untuk peduli, empati dan responsif dibutuhkan oleh pendidik untuk 
memberikan dorongan dan motivasi agar anak segera dapat bergabung dengan teman-temannya dalam kelompok belajar. Bahkan bukan hanya kepada anak sebagai siswa, guru dengan kompetensi kepribadian yang baik akan dapat memberikan motivasi dan pemahaman kepada orangtua siswa agar dapat bekerjasama dan saling memberikan kepercayaan satu sama laian untuk menangani siswa pada saat di sekolah.

4. Memiliki rasa kasih sayang, kesabaran, kehangatan, keluwesan, kejujuran, penuh perhatian, dan bersikap objektif. Rasa kasih sayang, kesabaran, dan kehangatan dibutuhkan untuk dapat membuat anak merasa diterima, didampingi, didukung, dicintai, sehingga tumbuh semangat serta kepercayaan diri dalam keseluruhan proses belajar. Keluwesan dibutuhkan oleh pendidik untuk secara kreatif mengelola pembelajaran, karena pembelajaran pada kelas anak usia dini terkadang tidak dapat berjalan seperti rencana pembelajaran yang telah dijadwalkan. Misalnya ketika ada siswa yang menolak belajar bersama temantemannya dan berada di kelas, maka pendidik dapat secara kondisional menyesuaikan diri secara luwes dengan minat anak pada saat itu. Guru dapat mengajarkan berhitung sederhana, misalnya dengan cara menghitung daun di bawah pohon di taman sekolah. Kejujuran dibutuhkan untuk memberikan teladan bagi anak didiknya, karena anak usia dini paling mudah belajar dengan cara meniru. Sikap penuh perhatian dibutuhkan untuk secara penuh mendampingi anak didiknya dalam belajar. Tanpa perhatian penuh, guru tidak dapat menghargai proses belajar anak, sehingga dikhawatirkan akan kehilangan progress atau laporan perkembangan anak dalam sebuah materi atau tahap belajar. Sikap objektif dibutuhkan oleh pendidik untuk dapat menilai perkembangan anak didik secara adil dan sesuai dengan pencapaian individualnya serta tidak membuat generalisasi umum perkembangan masingmasing siswa.

\section{SIMPULAN}

Kompetensi kepribadian pendidik anak usia dini berfungsi untuk merespon segala kejadian-kejadian di dalam kelas atau situasi pembelajaran yang berkenaan dengan sumber dan unsur pembelajaran. Kompetensi kepribadian tak hanya cukup untuk 
diri pendidik sendiri untuk tampil positif di dalam sebuah kelompok masyarakat atau lingkungan sekolah saja. Kompetensi ini dibutuhkan wujud nyatanya untuk merespon kejadian-kejadian di sekolah yang secara keseluruhan hal tersebut merupakan proses pembelajaran, terlebih dalam membantu keberhasilan proses penyesuaian diri siswa baru pada jenjang pendidikan anak usia dini, dimana aspek perkembangan sosial emosional siswa yang belum matang, untuk pertama kalinya dihadapkan pada lingkungan baru di luar lingkungan keluarganya. Karena proses pembelajaran yang sesungguhnya adalah penyelesaian masalah-masalah yang membutuhkan pemecahan, dan respon-respon individu dalam stimulus-stimulus kejadian. Kompetensi kepribadian ini menjadi salah satu jenis kompetensi yang lain yang harus dimiliki seorang pendidik untuk saling melengkapi menjadikan sosok pendidik yang professional.

\section{DAFTAR PUSTAKA}

Ahmadi, A. (1991). Sosiologi Pendidikan. Jakarta. Rineka Cipta.

Berns, R. M. (2010). Child, Family, School, Community: Socialization and Support. USA. Wadsworth.

Departemen Pendidikan Nasional (2005). Peraturan Pemerintah Republik Indonesia Nomor 19 Tahun 2005 Tentang Standar Nasional Pendidikan. Jakarta. Departemen Pendidikan Nasional.

Fatimah, E. (2006). Psikologi Perkembangan (Perkembangan Peserta Didik). Bandung. Pustaka Setia.

Hidayati, Laily (2011). Pelatihan Peningkatan Kompetensi Pendidik pada Jenjang Pendidikan Anak Usia Dini. Malang. UIN Malang.

Hurlock, E. (2003). Psikologi Perkembangan. Jakarta. Erlangga.

Jaya, Adisan. (2012) Peranan Penyesuaian Diri Dan Emosi Peserta Didik. http://adisastrajapenyesuaian-diridan.html. 9 Mei 2013.

Masitoh. (2005) Strategi Pembelajaran TK. Jakarta. Rineka Cipta. 
Patmodewo, Soemiarti. (2000). Pendidikan Anak Prasekolah. Jakarta: PT Rineka Cipta.

Suprobo, Noviana (2008). Penyesuaian Diri Anak TK. http://novinasuprobo.wordpress.com/2008/06/15/peny esuaian-diri-anak-tk/. 10 September 2012.

Susanti, Ani. dkk., Penyesuaian Diri Pada Anak Taman KanakKanak. EMPATHY, Jurnal Fakultas Psikologi. Vol. 1, No 1, Juli 2013

UU No. 20 Tahun 2003, tentang Sistem Pendidikan Nasional dan UU No. 14 Tahun 2005 tentang Guru dan Dosen. Jakarta. Visimedia.

UU No. 23 Tahun 2002, tentang Perlindungan Anak. Jakarta.Visimedia. 


\section{LAILY HIDAYATI}

50 | AL HIKMAH: INDONESIAN JOURNAL OF EARLY CHILDHOOD ISLAMIC EDUCATION | VOL.1 (1), 2017 